\title{
Between high autonomy and sovereign control in a subnational island jurisdiction: The paradox of Hong Kong under 'One Country, Two Systems'
}

\author{
Samson Yuen \\ Department of Political Science, Lingnan University, Hong Kong \\ samsonyuen@In.edu.hk
}

\author{
Edmund W. Cheng \\ Department of Public Policy, City University of Hong Kong, Hong Kong \\ wacheng@cityu.edu.hk (corresponding author)
}

\begin{abstract}
Hong Kong's 'One Country, Two Systems' formula has been hailed as an unprecedented political experiment in the People's Republic of China (PRC) for how it formulates a semi-autonomous jurisdiction within a unitary, single-party state. While the formula has remained constitutionally valid two decades after its implementation, it has been trapped in a tense relationship in actual practice. This article considers the city as a subnational island jurisdiction (SNIJ) and examines its scope for autonomy within and under an authoritarian sovereign state. It argues that the PRC's central government, prompted by the city's rising pro-democracy activism and its nascent pro-independence force, has put intensifying emphasis on the 'one country' principle by blurring the boundaries between the offshore enclave and the mainland through economic integration, connective infrastructures and legal harmonization. As a result, there is an increasingly blurred line between the 'two systems', structured and fostered by the enormous cross-border capital and people flow, although at times moderated and slowed down by local capitalist imperatives and social activism to resist homogenization. Our findings suggest that the contestation between autonomy and sovereign control cannot be read in purely constitutional terms but must be considered within the changing socioeconomic and legal context.
\end{abstract}

Keywords: autonomy, China, Hong Kong, One Country Two Systems (OCTS), sovereignty, subnational island jurisdiction (SNIJ)

https://doi.org/10.24043/isj.110 • Received August 2019, accepted March 2020

(C) 2020 - Institute of Island Studies, University of Prince Edward Island, Canada.

\section{Introduction}

Hong Kong's 'One Country, Two Systems' (OCTS) formula has been hailed as an unprecedented political experiment in the PRC for how it formulates a semi-autonomous jurisdiction within a unitary, single-party state. Devised in the early 1980s as a diplomatic deal 
to facilitate the transfer of sovereignty from the United Kingdom, the formula allows the former British colony to keep its governmental structure, capitalistic system, and legal regime after 1997 for 50 years without converging with China's state socialism. Two decades after its implementation, this constitutional design is now beset by tension. On the one hand, posthandover Hong Kong has maintained both its constitutional status as a Special Administrative Region of and in the People's Republic of China (PRC) and its capitalistic way of life which its residents once feared of losing. Its economy has thrived on a healthy fiscal reserve, low unemployment, and impressive growth by the standards of developed economies. Press freedom and human rights have been largely respected, unlike in Mainland China, and its civil society remains colorful and vibrant. On the other hand, despite undergoing some political reforms, the semi-autonomous city's progress of democratization has stalled Its political system remains authoritarian and oligarchic at its core, while recent authoritarian advances have further led to a rapid erosion of civic and political freedoms. These contrasting realities have epitomized the very paradox of OCTS: Is the maintenance of two distinct systems possible within a unitary and authoritarian state?

The development of OCTS is not merely a question for post-handover Hong Kong. It provides a valuable and unique case study to understand the extent of autonomy enjoyed by subnational island jurisdictions (SNIJs), a topic that has drawn much attention in island studies. While there has been a large body of research in island studies that deals with the topic, most of it focuses on SNIJs within democratic contexts, where the legality of power decentralization permits their existence. Few have studied how they have existed and fared in authoritarian regimes, in which state power is mostly centralized and monopolized. Although the lack of scholarly attention is in part due to the rarity of SNIJs in authoritarian contexts, the question deserves more traction not only because such cases do exist but also because it engenders a profound theoretical puzzle: can autonomous or semi-autonomous SNIJs meaningfully exist within unitary and authoritarian systems? How do authoritarian sovereigns structure their contours of autonomy?

This article addresses these questions by focusing on the case of post-handover Hong Kong. It argues that although SNIJs can remain constitutionally valid within authoritarian regimes, there are many nuanced ways to limit and undermine their autonomy. By examining the implementation of the OCTS formula, we argue that the PRC's central government, prompted by the city's rising pro-democracy activism and its nascent pro-independence force, has put intensifying emphasis on the 'one country' principle by blurring the boundaries between the offshore enclave and the mainland through economic integration, connective infrastructures and legal harmonization. The result is an increasingly blurred line between the 'two systems', structured and fostered by the enormous cross-border capital and people flow, although at times moderated and slowed down by local societal and capitalist resistances. Our findings suggest that the contestation between autonomy and sovereign control cannot be read in purely constitutional terms but must be considered within the changing socioeconomic and legal context.

\section{Subnational island jurisdictions under authoritarianism}

Decolonization since the early 20th century has left, in its wake, a large number of small-sized jurisdictions that are far away and culturally different from their colonial metropoles, many of 
which are islands or island-like territories. Although some of the larger territories swiftly gained independence, many other smaller territories remain dependent on their former colonizers or culturally distinct metropolitan for various reasons. Åland Islands in Finland, New Caledonia in France, Aruba in the Kingdom of the Netherlands, and, as we will discuss, Hong Kong in China, are only a few of many examples. Known by scholars as subnational island jurisdictions (SNIJs) due to their confined territorial space and insulation from the mainland or other land masses, these dependent territories are distinct political jurisdictions that often enjoy a large measure of autonomy in various policy areas, which give them the capacity to make their own administrative arrangements, legislate laws and formulate economic strategies. These island territories possessed varying degrees of autonomy and sovereignty prior to be integrated into the political system of a larger or external power. They also enjoy the capacity to practise what Bartmann (2006) calls para-diplomacy by developing formal diplomatic relations with other sovereign states. In short, even though SNIJs are not states and are constitutionally subordinate to their metropoles, they are "functionally" equivalent to small states (Baldacchino, 2010).

Due to their sheer numbers, size of populations, and contestable statuses, SNIJs have inspired an expanding body of research, especially in the field of island studies. Core to these burgeoning works is the question of autonomy. Island studies scholars have pursued three specific inquiries. The first is why the choice of dependence? Instead of seeking independence, why did many island territories make different power-sharing arrangements with their equivalent sovereign states, such as a special municipality, autonomous province, federal unit, and associated statehood (Baldacchino \& Milne, 2006, p. 494). Some scholars argue that this is a strategic choice (e.g. Baldacchino, 2010). Dependence can be economically beneficial while avoiding the chronic vulnerability that plagues small island territories (Briguglio, 1995). Various quantitative studies have confirmed this: residents of SNIJs are consistently more affluent, healthier and more educated than those of small sovereign states. (Armstrong \& Read, 2000; Bertram, 2004; McElroy \& Parry, 2012). For the metropolitan powers, there are different reasons for maintaining SNIJs. On the one hand, keeping SNIJs allows them to showcase their imperial reach in a soft manner, in a way that they would not be chastised for holding "colonies" (Baldacchino \& Milne, 2006). On the other hand, SNIJs may also be strategically useful, partly because SNIJs offer "unique offshore spaces outside the straitjacket of the increasingly restrictive, 'level-playing field' rules of global commerce among sovereign states" (Baldacchino \& Milne, 2006, p. 488; Baldacchino, 2012). SNIJs can serve as special economic zones, extraterritorial legal limbos, or territories for experimenting creative governance (Baldacchino, 2010).

The second question focuses on what autonomy is for SNIJs and how it is gained (or lost) vis-á-vis their metropoles. A geophysical separation from the mainland, distinct culture and constitutional guarantees are not sufficient conditions for autonomy. Prinsen and Blaise (2017) discuss a number of mechanisms that give SNIJs de facto jurisdictional powers-what they call 'islandian sovereignty'-including referendums, constitutional exceptions, and budgetary power. Karlsson (2009, p. 142) argues that robust SNIJs must also possess economic capacity: the "abilities (and skills) of the significant actors [...] to utilize existing and new resources in an efficient and innovative manner." These capacities allow SNIJs to thrive economically and choose a suitable developmental model without relying on transfers from their metropoles (Baldacchino \& Milne, 2000; McElroy \& Parry, 2012). 
A third question has recently emerged to probe how SNIJs' autonomy can be circumscribed under democratic frameworks, which supposedly facilitate power-sharing. For instance, Grydehøj (2016b) argues that, although democratic institutions discursively empower subnational governance of SNIJs, in practice they favor national governments and prevent subnational jurisdictions from expanding their governance capacity and exercising additional powers, thus hurting the quality of democracy. Hepburn (2014) reaches a similar conclusion: despite its constitutionally entrenched powers, a weak and indirect shared-rule arrangement with a centralized and unitary state can diminish a SNIJ's vis-á-vis its center. In short, discursive and constitutional promises of autonomy do not necessarily guarantee the actual practice of autonomy. One ought to carefully examine the institutional configurations through which SNIJ autonomy can be expressed.

No doubt, these works have contributed to a more complex understanding of what autonomy means for SNIJs in democratic contexts. But: what about SNIJs under authoritarian frameworks where power is by definition centralized and monopolized? So far, few studies have shed light on how SNIJs coexist with authoritarian sovereigns. The scant attention, to some extent, is understandable: authoritarian regimes seldom decentralize real power to subnational units, let alone allow them to form jurisdictions with unique constitutional status. Yet this begs the question because SNIJs do exist in authoritarian contexts. Obvious examples including Kish Island in Iran, and Macau and Hong Kong in China, while there are less obvious ones such as Zanzibar (a highly autonomous SNIJ within Tanzania, which has a deeply flawed democratic system) and North Cyprus/Turkish Republic of Northern Cyprus (a democratic de facto country that in many ways resembles a highly autonomous SNIJ of increasingly authoritarian Turkey). Why do authoritarian regimes allow SNIJs to exist in the first place? Through what levers do authoritarian sovereigns regulate their autonomy without altering the constitutional guarantees? More fundamentally, does autonomy mean anything in authoritarian contexts?

\section{Islandness of Hong Kong}

Post-handover Hong Kong offers a useful case for addressing these questions. To begin, Hong Kong is constitutionally designated as a special administrative region within authoritarian China after 1997, making it different from other provinces in Mainland China. Sheng, Tang, and Grydehøj (2017), for instance, regard the neighboring Special Administrative Regions of Hong Kong and Macau as 'Chinese island cities' due to their island spatiality and historical evolution in China's Pearl River Delta. Moreover, Hong Kong has historically enjoyed an island-like status even though, geographically speaking, it is made up of a combination of islands and a peninsula connected to Mainland China. Hong Kong had been colonized by the British for 156 years, during which it developed a Western-style politico-legal system, a capitalistic way of life, and relatively stable governance that contributed to its economic prosperity and shielded it from the political turmoil in the Mainland. Because of its favorable location, the city has cultivated a vast and extensive trading network, serving as a central node to a number of hinterlands across East Asia (Hamashita, 2013). Even though the majority of the population was ethnic Chinese, decades of colonial rule had brought in many foreigners from other parts of the British Empire, giving the city a cosmopolitan and outward-looking character. 
Hong Kong's colonial administration was able to enjoy a significant degree of autonomy even though London had overriding authority over the crown colony (Ngo, 1999). For instance, the governor was able to push back the Foreign Office's accommodating approach in handling the 1967 communist riots and persuaded London to adopt his policy of firm suppression of the local communists (Yep, 2008). During the social reforms in the 1970s, colonial administrators adamantly defended their vision of local interests and carried out the reforms at their own pace, despite pressure from London (Yep \& Lui, 2010). This sense of autonomy was also palpable for the average citizen. Although the British did not introduce democracy and would not hesitate to repress dissent for most of the period of colonial rule, they adopted indirect rule and relied heavily on the Chinese community to mediate conflicts and provide mutual help (Scott, 1989). Intervention into the people's social life was minimal, and there was no systematic effort to turn the locals into British citizens. Towards the end of the colonial rule, the British began to introduce democratic institutions to include citizens in policy-making process. Even though these reforms remained piecemeal and half-hearted, they did help to localize the administration and lend it some form of popular support.

The signing of the Sino-British Joint Declaration in 1984, however, raised serious doubts over whether and how the city's jurisdictional autonomy would continue. The declaration stipulated that Hong Kong would revert to Chinese control as a special administrative region under the principle of 'One Country, Two Systems' after 1997. The semi-autonomous city would be entitled to maintain a high degree of autonomy and its capitalistic way of life, without adopting the political and economic system of the socialist Chinese state. The Basic Law, which would serve as the city's mini constitution, also pledged to preserve much of the colonial system in the post-handover framework, including the partisan legislature, the British common law system and an independent judiciary. The power of final adjudication would be vested in local courts. Election for all members of the legislature is also included as an aspiration. Despite these constitutional assurances, the prospect of handover still evoked widespread anxieties (Holliday et al., 2004; Kwong \& Wong, 2017). Many feared that the city's economic prosperity and civic freedom could not be protected under the authoritarian Chinese state. These anxieties further intensified after China's brutal crackdown of the Tiananmen Movement in 1989, which prompted tens of thousands of people to emigrate overseas.

\section{Hong Kong under One Country, Two Systems}

The early post-handover years surprised and consoled many citizens as Hong Kong appeared able to uphold its high degree of autonomy. Although some democratic reforms introduced in the late colonial era were rolled back, Beijing adopted a largely non-interventionist approach to Hong Kong affairs. According to an unclassified document issued in the Mainland, the central government actually ordered local authorities not to intervene in Hong Kong (see Ma, 2007, p. 24). Although the position of the Governor had been replaced by that of a Chief Executive, changes to the political system practiced in the colonial era were kept to a minimum.

\section{Hong Kong as a window}

Hong Kong's initial autonomy was in part because Beijing hoped to continue its policy to leverage the special status of the territory to serve as a 'window' through which to engage 
with the outside world. During the Maoist era, China already adopted the guideline of "longterm planning and full utilization" with respect to Hong Kong in order to bypass the restrictions imposed by the United Nations sanctions after the Korean War. During that time, Hong Kong was an important place for Communist China to trade informally with the West and earn foreign currency (Carroll, 2005). Western medicines and technologies were often smuggled through the British colony to the Mainland. In the 1980s and 1990s, capital investment and business knowhow from Hong Kong became the main engines of economic growth in the Mainland, which helped to jumpstart China's 'Reform and Opening Up'. Even after China's accession to the WTO in 2001, Hong Kong has maintained its strategic importance. In particular, its trusted common law system and its well-developed financial system have helped many Mainland companies, including state-owned enterprises (SOEs), to raise capital. Between 2003 and 2013, the combined market capitalization of Mainland enterprises in the Hong Kong stock market amounted to US $\$ 1,484$ billion. By 2018, Hong Kong still accounted for more than $60 \%$ of foreign direct investment to Mainland China (Hong Kong Yearbook, 2018). Since the late 2000s, Hong Kong has also been designated as an offshore center to internationalize the Renminbi (RMB), China's currency.

Hong Kong's high degree of autonomy is not only recognized by its sovereign state. It is also guaranteed through international treaties and agreements regarding visa and immigration, export control, capital flow and postal services (Hung, 2018). Hong Kong enjoys para-diplomacy and maintains its separate membership in many international organizations, including the World Trade Organization, World Health Organization, AsiaPacific Economic Cooperation, the Olympic Games and the FIFA Football World Cup. It also ratified the International Covenant on Civil and Political Rights, while China did not. Meanwhile, the United States continued to recognize Hong Kong as a separate entity from China after the 1997 handover through its Hong Kong Policy Act (1992). Under this Act, the US would regularly verify and report on whether the semi-autonomous territory still enjoys substantial freedom and autonomy. If that is the case, the USA should "seek to maintain and expand economic and trade relations with Hong Kong, [...] continue to treat Hong Kong as a separate territory in economic and trade matters, such as import quotas and certificates of origin," and "continue to support access by Hong Kong to sensitive technologies controlled under the agreement of the Coordinating Committee for Multilateral Export Controls." So far, despite having amended the Act to require annual certification of Hong Kong's autonomy through the Hong Kong Human Rights and Democracy Act in November 2019, the USA has maintained its recognition of Hong Kong's autonomous status. This has set an example for other countries in seeing Hong Kong as a different entity from the Mainland, which continues to allow China to utilize the territory for capital investment, financial capitalization and technological transfer. Thus, for the sovereign state, keeping the autonomous status of Hong Kong-rather than making it equivalent to other Mainland cities-continues to serve state interests.

\section{Increasing momentum of mainlandization}

The year 2003 marked a drastic change in Beijing's policy towards Hong Kong. On 1 July that year, half a million people took to the streets to protest against an impending national security legislation that would criminalize treason, secession, subversion and sedition against the Chinese state. Pro-Beijing political parties suffered a humiliating defeat in the subsequent 
local elections. The protests also galvanized an emerging pro-democracy movement that gradually expanded into different issue areas, triggering mobilizations in the subsequent years with large turnouts and innovative tactics (Cheng, 2016). Though largely defensive in nature, these protests were seen by Beijing as threats to sovereign control (Ma, 2005). The 2014 'Umbrella Movement' was another peak in social mobilization that attested to the explosive power of Hong Kong's civil society (Lee \& Chan, 2018). Its failure to win any concessions from the authorities contributed to the rise of a nascent pro-independence movement (Veg, 2017). Considering this a national security threat, the central authorities increased their interference in local affairs through a mix of legal and extra-legal tactics (Yuen \& Cheng, 2017).

A second factor behind Beijing's tightening grip has to do with a more confident and resourceful sovereign relative to its Special Administrative Region. China quickly became the world's second largest economy after its accession to the WTO in 2001. Benefiting from market capitalization, many state-owned enterprises soon became a dominant economic force in Hong Kong. At the same time, the rise of Chinese nationalism in the 2008 Olympic Games, held mainly in Beijing, coincided with the recession in the many liberal democracies following the financial crisis. This critical juncture gave rise to a China Model discourse which promotes the view that Chinese state capitalism is more effective and resilient than Western liberal capitalism (Zhao, 2010).

Although Hong Kong remains strategic to the Mainland in many ways, it is clear that China is decreasing its reliance on Hong Kong capitalism as an intermediary force. Differential policies and strategic plans have been introduced to groom other Mainland cities such as Shenzhen and Shanghai as alternative business enclaves to replace the economic roles served by Hong Kong (Yao \& Whalley, 2016; O’Donnell, Wong, \& Bach, 2017). For local elites, therefore, maintaining their economic clout would mean further integrating Hong Kong into the political economy of the Chinese party-state. As a result, the business community became increasingly dependent on the Chinese market and political protection (Fong, 2014). Meanwhile, the sovereign state has changed its targets of co-optation from wealthy business and professional social elites, who would typically demand a certain degree of autonomy, to grassroots elites whose status and resources are dependent on state recognition and government resources (Cheng, 2020). In this light, the relationship between the communist state and the local capitalist class has gradually been transformed from a government-business partnership dependent upon shared economic interests to organizational patron-client relations that stress political allegiance.

\section{Capital and human flow}

In the post-handover era, although economic connection between the Mainland and Hong Kong remained strong, the integration between the two markets did not proceed in a symmetrical manner under the influence of Chinese state capitalism. This further blurred the boundaries of OCTS and brought serious repercussions.

Asymmetrical economic integration

Against the backdrop of China's accession to the WTO and Hong Kong's economic downturn following the 1997 Asian Financial Crisis and the 2003 SARS epidemic, the central government and Hong Kong government signed a free trade agreement in 2003, known as the Closer 
Economic Partnership Arrangement (CEPA). CEPA pledged to allow qualified companies to access the Mainland market and residents to enjoy preferential treatment when residing in the Mainland. A total of 15 supplementary CEPA agreements were signed between 2003 and 2019, covering four areas: trade in goods, trade in services, investment, and economic and technical cooperation. Under CEPA, Beijing agreed to fully implement zero tariffs on imported goods from Hong Kong. As a result, Hong Kong's domestic exports to the Mainland has soared from 3\% of total exports in 2004 to 38\% in 2013 (Hong Kong Yearbook, 2014).

As the first institutional arrangement of the Mainland-Hong Kong trade partnership, CEPA accelerated the economic integration between the two jurisdictions. The economic benefit brought by CEPA has, until now, been portrayed as a generous gift from the central government to Hong Kong people. But in many ways, it has benefited the Mainland enterprises more than Hong Kong enterprises. While Chinese capital has benefited hugely from Hong Kong's professional knowledge and financial arrangements, Hong Kong's economy and its capitalist class are increasingly integrated into the Mainland market and national planning, which weakened their bargaining power and political autonomy (Yuen, 2014).

Table 1. Market capitalization of Mainland enterprises in Hong Kong.

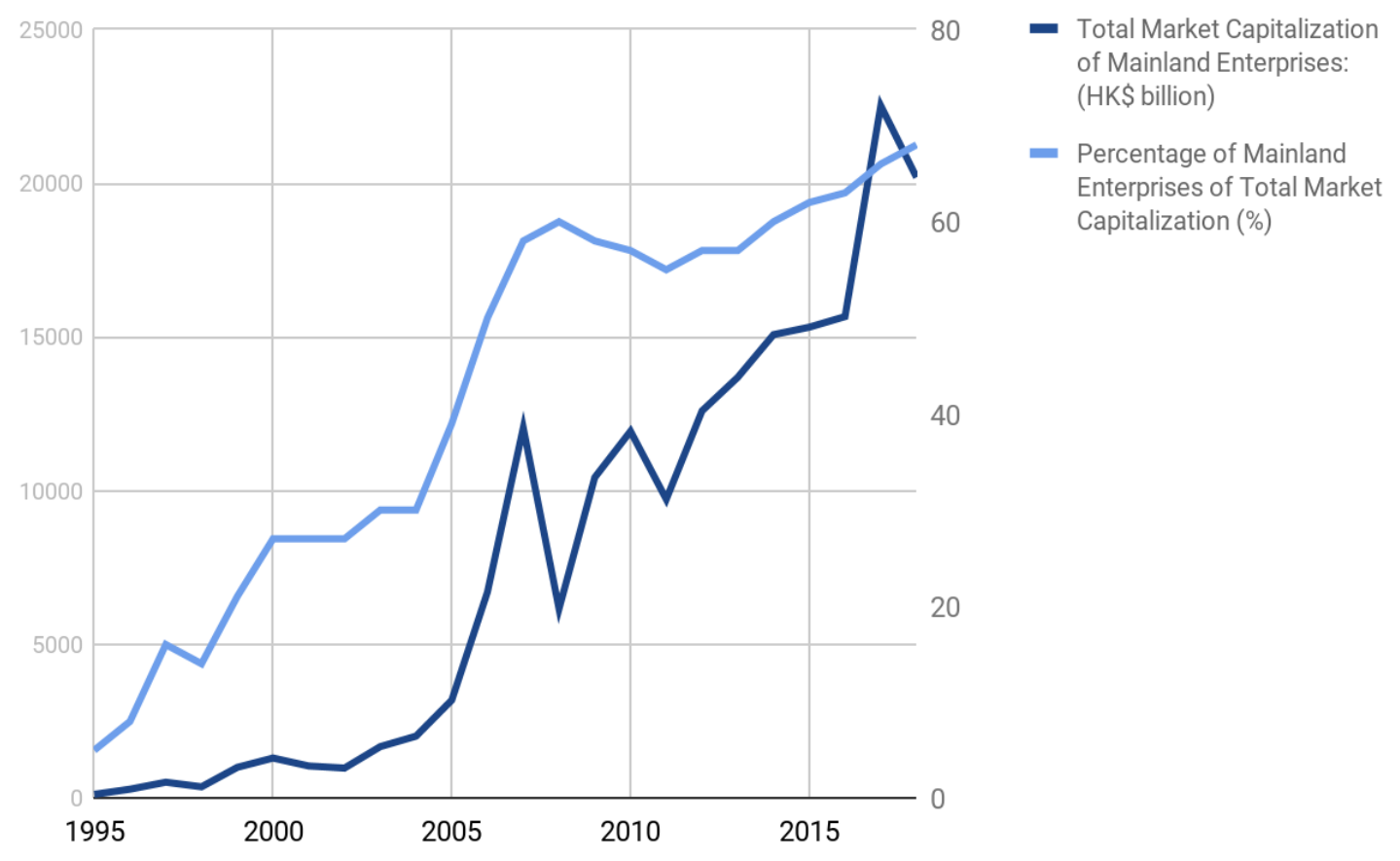

Source: Author compiled from Hong Kong Exchange and Clearing Market's Annual Market Statistics 1995-2018. Note: Mainland enterprises include H-share companies, red-chip companies and Mainland private companies.

The asymmetry of economic integration is further shown in the increasing financial presence of Mainland enterprises. Given Hong Kong's role as a center for offshore capitalraising, Mainland enterprises have dramatically increased their share in the stock market over the last two decades. Table 1 shows that the share of Mainland companies' market capitalization in Hong Kong rose enormously from 16\% in 1997 to 68\% in 2018. The remaining 32 percent of private local and foreign listed companies also earned a significant 
portion of their income from the Mainland market. Hong Kong only had 71 listed Mainland enterprises before the handover. As of 2018, the number of Mainland enterprises has surged to 1,146 , with a total market capitalization of $\operatorname{HK} \$ 20,193$ billion. In the same year, $95 \%$ of Initial Public Offering funds were raised from Mainland enterprises (HKEX, 2019, p.1).

What is remarkable about Hong Kong's economic integration with the Mainland is not only its speed and scale, but also its implications. In 1998, the top ten largest listed companies by market capitalization were all Hong Kong based or UK based companies, except China Mobile. In 2018, nine out of ten were Chinese enterprises, and all except one were SOEs. It is apparent that, as China becomes a global power, Chinese SOEs have penetrated Hong Kong's stock market, crowding out local and foreign companies. Hence, one may question whether the Hang Seng Index, a market-capitalization-weighted index of the local stock market, now represents the performance of Hong Kong's economy or that of Mainland China.

Given that China's capital account opening is institutionally constrained, Hong Kong's financial capacity and liquidity have played a critical role in RMB internationalization since the handover. In 2003, Hong Kong was the first offshore market to launch personal RMB business. The channels for the use of RMB in cross-border transactions with the Mainland have expanded significantly since 2009, when the Chinese authorities launched a pilot scheme for RMB trade settlement. In September 2009, the first RMB sovereign bond was issued in Hong Kong by China's Ministry of Finance. Since 2018, Hong Kong has been the largest offshore RMB clearing center, accounting for 75\% of the world's RMB payments ( HKEX, 2019).

The Chinese authorities have continued to strengthen the position of Hong Kong as a gateway for RMB internationalization. Speaking at a forum in February 2018, Zhang Dejiang, then-chief of the PRC's National People's Congress, identified Hong Kong as the first choice to pilot RMB internationalization. On the same occasion, the People's Bank of China's vice governor Fan Yifei said that Hong Kong possessed natural advantages that supported RMB settlement and monetary cooperation amongst Belt and Road Initiative countries and urged Hong Kong to engage in greater financial innovation to meet the needs of the Belt and Road Initiative concerning investment and risk avoidance products (SWIFT, 2018).

To further open up the Mainland capital markets, Shanghai-Hong Kong Stock Connect and Shenzhen-Hong Kong Stock Connect were implemented respectively in 2014 and 2016. These are cross-boundary investment channels linking the Mainland Stock Exchanges and the Hong Kong Stock Exchange. All trading will be settled in RMB. The cumulative turnover reached HK\$3,277 billion under both schemes by 2017. Hong Kong and international investors held a total of RMB 310 billion in Shanghai stocks and RMB 181 billion in Shenzhen stocks (HKEX, 2017).

These are clear signs that Hong Kong has been subsumed under national development plans and designated with the role of financial capitalization for Mainland enterprises. Its capitalist class has also exchanged its political allegiance to the sovereign for economic opportunities in the Mainland (Fong, 2014). Nevertheless, although the heightened economic integration has resulted in an increasingly blurred line between the two systems, the process has its consequences. In the anti-extradition bill protests of 2019, the local business sector expressed serious doubts. Many were worried that the bill, which was intended to allow the transfer of fugitives from the Special Administrative Region to the Mainland, would allow their assets to be confiscated by the authorities. Some of them openly opposed the bill while others passively resisted through the legislature or judicial reviews in local courts. Their 
resistance reflected their deep-seated but hidden distrust of the Communist legal system and their preference for Hong Kong's common law system. In fact, many Mainland officials and businessmen have invested heavily in Hong Kong's stock and property market after increased economic integration, which contributed to their own vested interest in preserving 'One Country, Two Systems'. In this sense, tensions in the semi-autonomous territory are more complex than they first seem. They are not just a binary tug-of-war between a central government seeking to centralize power and the local population wanting to preserve territorial autonomythey are a complex struggle involving multiple actors, including also Mainland state and private capital, local capitalists, and different levels of the national and local government.

\section{Rise of human flow and identity politics}

Besides the increase in capital flow, cross-border human flows have also been growing between Hong Kong and the Mainland. These flows were supported by a series of government policies, which significantly altered the city's demography and gave rise to identity politics.

To begin, under the agreement between the British colonial government and the Mainland Chinese authorities, a One-Way Permit (OWP) scheme with 75 daily quotas was introduced in 1982 to control the scale of legal immigration while reducing illegal immigration. At present, the daily quota for Mainland residents coming to Hong Kong for settlement through OWP has been increased to 150, including 60 reserved for persons who were born in the Mainland and have right of abode in Hong Kong by descent from either of their parents, and 30 reserved for long-separated spouses. According to the government, around one million Mainland residents entered Hong Kong on OWP between 1997 and 2018. The entire application process, including screening, approval and issuing, is under the remit of the Mainland authorities. The Hong Kong government has no say in it at all. As a result, the scheme has been subject to long-standing controversy in Hong Kong society. Many citizens criticize that the growing number of Mainland residents has placed heavy pressure on local public services such as housing, education, healthcare and social welfare, while giving electoral advantages to pro-Beijing political parties.

Second, an Individual Visit Scheme (IVS) was implemented in July 2003 as a tourism liberalization measure under CEPA to boost the ailing tourism industry after the SARS outbreak. The IVS allowed residents of designated Mainland cities to visit Hong Kong on an individual basis without being required to join group tours. As of now, the scheme has been extended to 49 cities, including major cities in the Pan-Pearl River Delta together with municipalities such as Beijing and Shanghai. Given the increasing ease of traveling, the number of Mainland visitors has been surging. In 2002, there were 17 million visitors coming to Hong Kong, and 41\% came from the Mainland. By 2018, the number of visitors had risen to 65 million, and $79 \%$ were Mainland visitors, out of which $60 \%$ were daytrippers (a significant proportion of which are parallel traders who smuggle goods across the border) ( HKTB, 2019). During the same period, the contribution of tourism to Hong Kong's GDP has doubled. Although its real contribution to the economy is not as significant as is often portrayed, increased inbound tourism has certainly generated huge pressure on Hong Kong's transportation system and citizens' daily lives.

Third, in order to meet Hong Kong's human resource needs, the Hong Kong government introduced the Admission Scheme for Mainland Talent and Professionals (ASMTP) in 2003 to attract qualified Mainlanders. In 2006, the government further launched 
the Quality Migrant Admission Scheme (QMAS), a point-based entrant scheme that targets highly skilled persons from around the world to settle in Hong Kong without requiring an offer of local employment before making an application. Both schemes have brought tens of thousands of immigrants to Hong Kong each year. Although Mainland and non-Mainland applications for QMAS were roughly equal, more than $86 \%$ of the quota was allocated to Mainland applicants between 2015 and 2017.

Under the broader socio-economic context, the vast cross-border human flow has blurred the line between the two separate systems. Research in 2004 suggested that political orientation of young immigrants who have studied in the local education system for more than seven years are identical to those of locally born residents (Cheng, 2004). However, since the majority of the new Chinese immigrants entering through the above schemes are mostly either middle-aged professionals or middle-aged women seeking to reunite with their husbands, the assimilation mechanism that counts on the long-term effect of civic education does not kick in. Pro-Beijing political groups have also used economic interests and their nationalistic sentiments to co-opt these new immigrants to support the policy of greater integration (Cheng, 2020). The combined result is that Mainland immigrants tend to support conservative and pro-regime political parties in their voting preferences (Wong et al., 2016).

The threat towards the liberal institutions that have differentiated the two systems became more imminent following 2009, resulting in the rise of a 'localist' discourse (Cheng \& Chan, 2017). This localist discourse is not the kind of right-wing populism that has emerged in Western democracies but closer to that of peripheral nationalisms (Fong, 2017), which unfolded through a distinction between Hong Kong and pan-Chinese identities, along a mode of identification that differentiates between the civic and the ethno-cultural. Although a robust sense of local identity had already emerged in Hong Kong since the 1970s, the majority of the Hong Kong people long possessed a pan-Chinese identity. It was only in the 2010s that they began perceiving Mainlanders as 'others'. A regular opinion poll shows that the number of Hong Kong people who identify as 'Chinese' has been steadily declining since 1997. In 2019, only 11\% of the respondents considered themselves 'Chinese' and 12\% 'Chinese in Hong Kong', while 53\% considered themselves 'Hongkongers' and 23\% 'Hongkongers in China'. This growing local identification, accompanied by a growing localist discourse, has made identity politics a "zeitgeist" in Hong Kong society, prompting a series of eventful protests that sought to curb cultural harmonization with the Mainland (Veg, 2017).

SNIJs around the world host a mix of immigration systems, with some imposing immigration control on individuals from the metropolitan state and others not doing so. There are few obstacles for citizens of the metropole to immigrate to and work in Greenland relative to Denmark, New Caledonia relative to France, and Jeju Island relative to South Korea. These SNIJs are not free from ethnic tensions (e.g. Grydehøj, 2016a; Korson, 2018; Kim, 2020), but the autonomous governments lack control over immigration. Nevertheless, other SNIJs restrict immigration and/or working rights for citizens of the metropole, such as Åland relative to Finland and Bermuda and the Isle of Man relative to the UK. SNIJmetropole relationships around the world are frequently associated with varying concerns over labor and lifestyle immigration: for example, Åland in Finland and the Crown Dependencies of the UK all possess a degree of control over immigration and labor rights, which is significant given the appeal these affluent SNIJs hold for metropolitan labor. Even SNIJs that are economically less well off than their metropole and that lack immigration and 
labor control are often targets for specific kinds of labor migration, for instance related to jobs in government administration, sometimes with socially damaging impacts (e.g. Grydehøj, 2020). Relative to other SNIJs around the world, Hong Kong possesses exceptionally strong ability to control immigration from the Mainland, though as discussed above, this control is mitigated by various admission schemes. Nevertheless, in Hong Kong, there is a palpable fear of demographic takeover accompanied by political takeover and cultural disappearance. Despite China's economic growth, Hong Kong's standards of living - in terms of investment opportunity, property protection, education, and medical care - are still perceived by many Mainland Chinese to be more appealing.

In other words, the impact of China's authoritarianism on Hong Kong's autonomy is complex. The trouble is less that a metropole has centralized authority over immigration on account of its authoritarianism and more that the authoritarianism of the metropole renders life in the autonomous SNIJ more desirable.

\section{Infrastructural connectedness}

If capital and human flows fostered integration between Hong Kong and the Mainland, then connective infrastructures are what made them physically possible. In the past two decades, numerous infrastructural projects were undertaken to enhance connectedness with the Mainland. The most recent completion was the HK\$96 billion Hong Kong-Zhuhai-Macau Bridge, the longest fixed link on Earth, which connects Hong Kong to the other side of the Pearl River Delta. Projects like this have significantly reduced the time to travel to different parts of southern China and result in a growing number of cross-border control points. Table 2 shows that the number of checkpoints increased from five in 1997 to ten in 2019. Four of these are rail-based land crossings, while the other six are road-based. For instance, the Liantang Border Control Point has reduced the average travelling time between Northern Hong Kong and Eastern Shenzhen from over 50 minutes to around 30 minutes, thus further facilitating human and cargo flows across the border.

Table 2. Boundary control points in Hong Kong.

\begin{tabular}{llll}
\hline Control Points & Opened & Type of crossing & Hours \\
\hline Lo Wu & 1887 & Rail-based & $06: 30-00: 00$ \\
\hline Hung Hom & 1975 & Rail-based & $06: 45-23: 15$ \\
\hline Man Kam To & 1978 & Road-based & 07:00-22:00 \\
\hline Sha Tau Kok & 1985 & Road-based & $07: 00-22: 00$ \\
\hline Lok Ma Chau & 1989 & Road-based & 24 hours \\
\hline Shenzhen Bay & 2007 & Road-based & $06: 30-00: 00$ \\
\hline Lok Ma Chau Spur Line & 2007 & Rail-based & $06: 30-22: 30$ \\
\hline Hong Kong-Zhuhai-Macao Bridge & 2018 & Road-based & 24 hours \\
\hline Express Rail Link West Kowloon & 2018 & Rail-based & $06: 30-23: 30$ \\
\hline Liantang/Heung Yuen Wai & 2019 & Road-based & Pending \\
\hline
\end{tabular}

In addition to dissolving the physical borders, these connective infrastructures have the effect of blurring the legal arrangement of border control. The Guangzhou-Shenzhen-Hong 
Kong Express Rail Link (XRL), which effectively connects Hong Kong to the national highspeed railway network, is particularly illustrative. Despite fierce resistance against its construction in 2009 and 2010, the XRL was eventually approved by the Legislative Council due to the domination of the pro-Beijing camp. As the construction approached its completion, controversy over the XRL reemerged concerning a co-location arrangement between the Mainland and Hong Kong, which would allow Mainland officers to be stationed in Hong Kong's territory and enact Chinese laws. Notwithstanding huge criticism from lawmakers and civil society groups that the arrangement would violate the Basic Law, the Standing Committee of China's National People's Congress unilaterally approved the arrangement. This decision closed the possibility for judicial review of the government's decision.

These infrastructural projects were the preludes to a bigger plan to integrate Hong Kong into national development. The Guangdong-Hong Kong-Macao Greater Bay Area, officially announced by the State Council in February 2019, is indicative in this respect. The Greater Bay Area, which includes Hong Kong, Macau and nine Pearl River Delta cities, was designed to leverage the advantages of the open economies of Hong Kong and Macau and the innovation and manufacturing hubs in Guangdong Province to find a new growth engine for China. According to the Outline Development Plan, Hong Kong is designated as a core city to drive regional development and to support the global Belt and Road Initiative. It will work with other PRC cities to establish a market-oriented business environment that promotes the free flow of talent, goods and capital across the region. A series of initiatives was subsequently developed to attract investment and labor from Hong Kong to settle in the Greater Bay Area, such as lower tax rates for Hong Kong citizens working in the area.

In sum, these connective infrastructures provided the physical foundation for greater economic integration. To some extent, one may argue that economic integration has also spilled over to the political realm. In 2018, the current Chief Executive Carrie Lam was appointed to a 'leading small group' created by Beijing to plan the development of the Greater Bay Area. Leading small groups are powerful decision-making bodies in the PRC (Miller, 2017). The Greater Bay Area Leading Small Group, chaired by a Politburo Standing Committee member of the Chinese Communist Party, serves as a coordinating body for these 11 cities and makes top-level decisions to implement policies regarding the Greater Bay Area's development. Besides Lam, members of the group include representatives from central ministries and Guangdong's provincial government. This institutional arrangement is the first of its kind: it means that Hong Kong is formally absorbed into the state-socialist national development with a designated position and function.

\section{Harmonization of two legal systems}

In addition to asymmetric economic integration and increasing infrastructural connectedness, legal harmonization was another means of control adopted by the central government to diminish the high autonomy of its subnational entity. By legal harmonization, we refer to the process of dissolving the boundaries between the central and local legal systems, which come from very different traditions.

Hong Kong has a long tradition of practicing the rule of law based on the British common law system, which is distinct from the legal system adopted in the Mainland. According to the Basic Law, Hong Kong courts could exercise judicial independence and 
enjoy the authority of final adjudication. However, the central authorities also possess the right to reinterpret the Basic Law, which effectively constrains the local legal and judiciary systems. Moreover, the opposition or the pro-democracy camp has been institutionally constrained to be a minority in the Legislative Council under Hong Kong's hybrid regime system (Wong, 2015). This means that the Hong Kong government and pro-Beijing parties can relatively easily enact laws that preserve their interests and implement the central government's policies. Articles 45 and 68 of the Basic Law respectively promise the election of the Chief Executive and the members of the Legislative Council by universal suffrage but do not specify the exact electoral methods and are deliberately vague as to how elections should be organized. For example, Article 45 states that election of the Chief Executive must occur following nomination by a broadly representative nominating committee. The formation of this nominating committee is not specified, nor is 'broadly representative' defined. It has thus largely been left to the central government to interpret the law.

The interpretation of the Basic Law was an exemplar of how legal harmonization takes place through political means. According to Article 158, the power of interpretation is vested in the Standing Committee of the National People's Congress. However, from a procedural point of view, the interpretation power has to be exercised under three criteria (Chan, 2016). First, the interpretation must be issued in relation to Basic Law provisions that concern the PRC government's responsibilities or the relationship between the PRC government and Hong Kong. Second, the interpretation must be requested by the Hong Kong Court of Final Appeal, except for matters concerning national sovereignty. Third, the interpretation should be an interpretation rather than an amendment of the law.

Historically, there were five occasions in which the Basic Law was interpreted, including the right of abode in 1999, the election of the Hong Kong Chief Executive in 2004, the decision to replace the Chief Executive in 2005, the Democratic Republic of Congo's right to diplomatic immunity in 2011, and the controversy over the oath-taking by elected representatives for public office in 2016. Most of these occasions have led to debates over the extent of judicial independence of the local system and the adverse impact of the interpretations on Hong Kong's autonomy. Among these five interpretations, only the Congo case met all three criteria.

The oath-taking saga was particularly salient and deserves further elaboration. Since 2004, the oath-taking ceremony of the inaugural session of each newly elected legislature has been an arena for pro-democracy elects to stage a symbolic protest act. This was no exception in the inaugural meeting of the sixth legislature in October 2016. In particular, two proindependence legislators displayed a banner that said "Hong Kong is not China" and swore allegiance to the "Hong Kong nation" in their oath-taking ceremony. The President of the Legislative Council invalidated their oaths. Thereafter, the Chief Executive and the Secretary for Justice launched a judicial review, seeking to formally disqualify the two legislators. On 17 November 2016, the Standing Committee of the National People's Congress convened a special session to reinterpret Article 104 of the Basic Law on what constitutes a "not sincere or not solemn" oath-taking. It specified that those who committed this offence should be barred from taking office and from retaking the oath and applied its interpretation retrospectively. Bound by this reinterpretation, the Hong Kong court officially unseated the legislators. In the following month, another four pro-democracy legislators were also unseated by the court for having made "insincere" oaths. 
The Court of Final Appeal eventually rejected the disqualified legislators' final appeal application in September 2017. According to the verdict, the appeal committee asserted that the case would have "led to the same conclusion to unseat the pair even without Beijing's interpretation" (Lau, 2017). Furthermore, the judgment also established that solemnity and sincerity are essential in oath-taking for assuming public office. In other words, the judgement ruled that the lawmakers' oaths were insincere. In the end, six lawmakers were disqualified, stripping the pro-democracy camp of its veto power in the legislature.

This latest Basic Law interpretation outlined a detailed, yet controversial, standard of a "sincere oath" during the swearing-in ceremony for public offices in Hong Kong. To a large extent, the power to judge "sincerity" depended merely on how the oath-taking commissioner interprets, without any external party to guarantee. The role of these officers has been challenged by all 30 legal sub-sector members of the Chief Executive election committee, who raised concerns over the potential for political censorship based on subjective decisions by civil servants. The impact of the interpretation went beyond the oath-taking saga. Since then, disqualifying the opposition from electoral contests has become a habitual practice by the Hong Kong government. The impact has been profound: after the opposition lost its veto power in the legislature, the pro-Beijing camp swiftly rewrote the rulebook to ban filibustering, a means that opposition members had used to stall controversial bills.

The direct intervention from the Standing Committee of the National People's Congress reflected that the central government has adopted a more hardline position. In fact, in June 2014, the State Council already issued a white paper to outline Beijing's policy towards the practice of the 'One Country, Two Systems' framework. This unprecedented document emphasized that, given that China is a unitary state, the central government has "comprehensive jurisdiction" over Hong Kong, and the territory's high degree of autonomy is not "an inherent power, but one that comes solely from the authorization by the central leadership" (Information Office of the State Council, 2014). The white paper also went on to state that judges and judicial personnel were part of Hong Kong's "administrators" and hence are expected to be patriotic. This is in direct contravention of the principle of the separation of powers as promised by the Basic Law.

China is not alone in insisting that it is the legal arbiter of the autonomous status of its SNIJs. This issue arises in democratic contexts as well. Recently, for example, Denmark has unilaterally intervened to prevent Chinese companies from operating in Greenland, although this is a policy area over which Greenland should have de jure authority, and Danish politicians have insisted that Greenlandic autonomy is governed by Danish parliament (Grydehøj, 2020). Similarly, there have been periodic discussions about the UK's constitutional duty or ability to intervene in its Overseas Countries and Territories and its Crown Dependencies on human rights grounds (Barker, 2016) or in order to prevent or in order to prevent these SNIJs from functioning as 'tax havens' (Cobham \& Gibson, 2016). The Netherlands has likewise intervened in the politics of Curaçao, a highly autonomous SNIJ (Phillip-Durham, 2020). Furthermore, there are numerous examples of democratic countries that have treated their SNIJs oppressively or that have exercised sovereignty over colonized SNIJs without unambiguous Indigenous consent, such as Bougainville relative to Papua New Guinea (Regan, 2014) and Guam and Hawaii relative to the US (Santos Perez, 2019; Garrison, 2019). 


\section{Conclusion}

There are many SNIJs around the world that enjoy a substantial degree of autonomy vis-á-vis their metropoles, although how such autonomy works in practice varies widely across contexts. But what about SNIJs in authoritarian contexts? Does autonomy mean anything for these SNIJs? This article has sought to provide an empirically grounded perspective through the case of post-handover Hong Kong, a semi-autonomous territory governed by authoritarian China.

Although Hong Kong has been guaranteed a high degree of autonomy under the 'One Country, Two Systems' principle, its actual ability to exercise autonomy has diminished over time. This article has focused on three ways - economic integration, connective infrastructures and legal harmonization - through which the PRC government exerts sovereign control and blurs the boundaries between the offshore enclave and the Mainland. The findings demonstrate the fragility of SNIJ autonomy in authoritarian contexts, despite the potential strategic value that SNIJs hold for their metropoles. Their autonomy may be considered a threat to the unitary nature of authoritarian states. They also show that constitutions only minimally guarantee their entitlement to autonomy. The scope of autonomy must also be considered within the broader socio-economic and legal context, taking into account various levers utilized by the authoritarian sovereigns.

The erosion of SNIJ autonomy, however, does not need to follow a linear, onedirectional trajectory; it may sometimes be slowed down and subverted by social resistances. The spectacular protests triggered by the amendment to the Fugitive Offenders Ordinance in 2019 is a pertinent example. The proposed bill, which would allow the transfer of fugitives to the Mainland and appeared likely to be passed in a legislature dominated by pro-Beijing members, sparked widespread fears that it would remove the firewall between the two distinct legal systems and become the final straw that completes Hong Kong's legal harmonization with the PRC. Besides the rarely seen opposition from the local business communities, a series of mass demonstrations took place in various places in the city, the largest of which attracted an alleged turnout of two million people. The protests eventually forced the Hong Kong government to suspend the bill and issue a public apology, halting the trajectory of legal harmonization. But as the protests continued to press the government for the complete withdrawal of the bill and other demands through increasingly militant actions, Beijing began to endorse a hardline repression through the local police force, arresting and prosecuting frontline protesters. As the political crisis is still unfolding at the time of writing, whether this would result in the further erosion of Hong Kong's autonomy remains to be seen. The contestation between high autonomy and sovereign control is likely to continue to be a defining theme of Hong Kong's politics.

Importantly though, the issue of metropolitan intervention is not exclusive to SNIJs in authoritarian contexts. It is also relevant to those in democracies. Recent events have shown that democratic metropolitan states can overstep the boundaries that give rise to the autonomy of SNIJs. Metropolitian states, whether democratic or authoritarian, may be apt to assert constitutional dominance over their autonomous SNIJs and seek to keep them economically and politically dependent. How, then, does metropolitan intervention in SNIJs differ between authoritarian and democratic contexts? If the people of SNIJs regard metropolitan intervention as an imposition regardless, does it matter whether the regime acts in an 
authoritarian or a democratic manner in the metropole itself? The present study suggests that having an authoritarian metropole may matter in the sense that it can render the autonomous SNIJ more attractive to residents of the metropole. By the same token, the contrasts between cultural, political, and economic conditions in the SNIJ and the metropole may place special impetus on an authoritarian metropole to seek to bring a divergent SNIJ into line.

We can at present make no more than provisional comments. A firmer understanding of the effect of authoritarianism on SNIJ autonomy would require robustly comparative crossnational research. Such research could also help grapple with issues surrounding undemocratic or illiberal autonomous SNIJs within democratic metropolitan states, such as the pre-2008 feudal island of Sark (an SNIJ of the UK), (Johnson, 2014) or the numerous small island territories in which "powerful informal tendencies towards authoritarian politics are in fact encapsulated within a formally democratic system" (Veenendaal, 2020, p. 34).

\section{References}

Armstrong, H. W., \& Read, R. (2000). Comparing the economic performance of dependent territories and sovereign microstates. Economic Development and Cultural Change, 48(2), 285-306. https://doi.org/10.1086/452459

Barker, N.J. (2016). 'I wouldn't get unduly excited about it': The Impact of the European Convention on Human Rights on the British Overseas Territories. A Case Study on LGBT Rights in Bermuda. Public Law, 2016(4), 595-612.

Baldacchino, G. (2010). Island enclaves: Offshoring strategies, creative governance, and subnational island jurisdictions. Montreal, Canada: McGill-Queen's University Press. https://doi.org/10.1177/1474474013478369

Baldacchino, G. (2012). Islands and despots. Commonwealth \& Comparative Politics, 50(1), $103-$ 120. https://doi.org/10.1080/14662043.2012.642119

Baldacchino, G., \& Milne, D. (2006). Exploring sub-national island jurisdictions: an editorial introduction. The Round Table: Commonwealth Journal of International Affairs, 95(386), 487-502. https://doi.org/10.1080/00358530600929735

Bertram, G. (2004). On the convergence of small island economies with their metropolitan patrons. World Development, 32(2), 343-364. https://doi.org/10.1016/j.worlddev.2003.08.004

Briguglio, L. (1995). Small island developing states and their economic vulnerabilities. World Development, 23(9), 1615-1632. https://doi.org/10.1016/0305-750x(95)00065-k

Carroll, J.M. (2005). Edge of empires: Chinese elites and British colonials in Hong Kong. Cambridge, MA: Harvard University Press. https://doi.org/10.4159/9780674029231

Cheng, E.W. (2016). Street politics in a hybrid regime: The diffusion of political activism in post-colonial Hong Kong. China Quarterly, 226, 383-406. https://doi.org/10.1017/s0305741016000394

Cheng, E.W., \& Chan, W.Y. (2017). Explaining spontaneous occupation: antecedents, contingencies and spaces in the Umbrella Movement. Social Movement Studies, 16(2), 222-239. https://doi.org/10.1080/14742837.2016.1252667

Cheng, E.W. (2020). United front work and mechanisms of counter-mobilization in Hong Kong. China Journal. 83, 1-33. 
Cheng, R.H. (2004). Moral education in Hong Kong: Confucian-parental, Christianreligious and liberal-civic influences. Journal of Moral Education, 33(4), 533-551. https://doi.org/10.1080/0305724042000315626

Cobham, A., \& Gibson, L. (2016). Ending the Era of Tax Havens: Why the UK government must lead the way. Oxfam Briefing Paper. Oxford: Oxfam.

Fong, B.C. (2014). The partnership between the Chinese government and Hong Kong's capitalist class: Implications for HKSAR governance, 1997-2012. China Quarterly, 217, 195-220. https://doi.org/10.1017/s0305741014000307

Fong, B.C. (2017). One country, two nationalisms: Center-periphery relations between Mainland China and Hong Kong, 1997-2016. Modern China, 43(5), 523-556. https://doi.org/10.1177/0097700417691470

Garrison, R. (2019). Settler responsibility: Respatialising dissent in 'America' beyond continental borders. Shima, 13(2), 56-75. https://doi.org/10.21463/shima.13.2.07

Grydehøj, A. (2020). Unravelling economic dependence and independence in relation to island sovereignty: The case of Kalaallit Nunaat (Greenland). Island Studies Journal, 15(1). https://doi.org/10.24043/isj.101

Grydehøj, A. (2016a). Navigating the binaries of island independence and dependence in Greenland: Decolonisation, political culture and strategic services. Political Geography, 55(1), 102-112. https://doi.org/10.1016/j.polgeo.2016.09.001

Grydehøj, A. (2016b). Toward subnational democracies of scale: Tensions between democratic legitimacy, legality, and effective governance. Geopolitics, 21(1), 22-42. https://doi.org/10.1080/14650045.2015.1114918

Hamashita, T. (2013). China, East Asia and the global economy: Regional and historical perspectives. London: Routledge.

Hepburn, E., \& Zapata-Barrero, R. (Eds.) (2014). The politics of immigration in multi-level states: Governance and political parties. Berlin: Springer. https://doi.org/10.1057/9781137358530.0008

HKEX (2019a). HKEX Fact Book 2018. Hong Kong: Hong Kong Exchanges and Clearing Market. Retrieved from https://www.hkex.com.hk/-/media/HKEXMarket/Market-Data/Statistics/Consolidated-Reports/HKEX-Fact-Book/HKEXFact-Book-2018/FB 2018.pdf

HKEX (2019b). Stock connect continues to grow as cross-border trading scheme marks 3rd anniversary. Hong Kong Exchanges and Clearing Market Press Release. Retrieved from https://www.hkex.com.hk/News/News-Release/2017/171114news?sc lang=en

HKTB (2019). Hong Kong Tourism \& Travel Industry Statistics. Hong Kong: Hong Kong Tourism Board.

Holliday, I., Ma, N., \& Yep, R. (2004). After 1997: The dialectics of Hong Kong dependence. Journal of Contemporary Asia, 34(2), 254-270.

Hung, H.F. (2018) Sanction Hong Kong, for its own sake. Journal of Political Risk, 7(10). Retrieved from https://www.jpolrisk.com/sanction-hong-kong-for-its-own-sake/

Information Office of the State Council of the People's Republic of China (2014). The Practice of the 'One Country, Two Systems' Policy in the Hong Kong Special Administrative Region. Retrieved from http://www.scio.gov.cn/zfbps/ndhf/2014/Document/1373163/1373163.htm 
Johnson, H. (2014). Sark and Brecqhou: Space, politics and power. Shima, 8(1), 9-33.

Karlsson, A. (2009). Sub-national island jurisdictions as configurations of jurisdictional powers and economic capacity: Nordic experiences from Åland, Faroes and Greenland. Island Studies Journal, 4(2), 139-162.

Kim, S.P. (2020). Mainland development policy in an autonomous subnational island jurisdiction: spatial development and economic dependence in Jeju, South Korea. Island Studies Journal, 15(1). https://doi.org/10.24043/isj.76

Korson, C. (2018). Framing social rebalancing, national identity, and victimhood in Kanaky/New Caledonia. Social \& Cultural Geography, 19(5), 549-575. https://doi.org/10.1080/14649365.2017.1286372

Kwong, Y.H., \& Wong, M.Y.H. (2017). State size and democratization in hybrid regimes: the Chinese island cities of Macau and Hong Kong. Island Studies Journal, 12(2), 113126.

Lau, C. (2017). Top Hong Kong court explains rejection of lawmakers' appeal bid and reinforces Beijing's limited role in legal system. South China Morning Post, 1 September.

Ma, N. (2007). Political development in Hong Kong: State, political society, and civil society (Vol. 1). Hong Kong University Press. https://doi.org/10.1017/s0305741007001919

Ma, N. (2005). Civil society in self-defense: The struggle against national security legislation in Hong Kong. Journal of Contemporary China, 14(44), 465-482. https://doi.org/10.1080/10670560500115416

McElroy, J.L., \& Parry, C.E. (2012). The long-term propensity for political affiliation in island microstates. Commonwealth \& Comparative Politics, 50(4), 403-421. https://doi.org/10.1080/14662043.2012.729727

Miller, A. (2017) The CCP Central Committee's leading small groups. In E.K. Brodsgaard (Ed.), Critical readings on Communist Party of China (pp. 279-303). Leiden: Brill. https://doi.org/10.1163/9789004302488 011

Ngo, T.W. (Ed.) (1999). Hong Kong's history: State and society under colonial rule. London: Routledge.

O’Donnell, M.A., Wong, W., \& Bach, J. (Eds.) (2017). Learning from Shenzhen: China's postMao experiment from special zone to model city. Chicago: University of Chicago Press. https://doi.org/10.7208/chicago/9780226401263.001.0001

Phillip-Durham, G. (2020). Continuity, change and constraints in the island institutional landscapes of Curaçao, Sint Maarten and Trinidad and Tobago. Island Studies Journal, 15(1).

Prinsen, G., \& Blaise, S. (2017). An emerging 'Islandian' sovereignty of non-self-governing islands. International Journal, 72(1), 56-78. https://doi.org/10.1177/0020702017693260

Regan, A.J. (2014). Bougainville: Large-scale mining and risks of conflict recurrence. Security Challenges, 10(2), 71-96.

Santos Perez, C. (2019). Guåhan, the Pacific and decolonial poetry. Shima, 13(2), 22-29.

Scott, I. (1989). Political change and the crisis of legitimacy in Hong Kong. Honolulu HI: University of Hawai'i Press.

Sheng, N., Tang U.W., \& Grydehøj, A. (2017). Urban morphology and urban fragmentation in Macau, China: island city development in the Pearl River Delta megacity region. Island Studies Journal, 12(2), 199-212. https://doi.org/10.24043/isj.25 
SWIFT (2018). Hong Kong, United Kingdom, Mainland China - leading RMB internationalisation. SWIFT RMB Tracker. April 2018.

Veenendaal, W. (2020). Islands of democracy. Area, 52(1), 30-37. https://doi.org/10.1111/area.12462

Veg, S. (2017). The rise of "localism" and civic identity in post-handover Hong Kong: Questioning the Chinese nation-state. China Quarterly, 230, 323-347. https://doi.org/10.1017/s0305741017000571

Wong, M.YH. (2015). Party models in a hybrid regime: Hong Kong 2007-2012. China Review 15(1), 67-94.

Wong, S. H.W., Ma, N. and Lam, W. M. (2016) Migrants and democratization: The political economy of Chinese immigrants in Hong Kong. Contemporary Chinese Political Economy and Strategic Relations, 2(2), 909-940.

Yao, D., \& Whalley, J. (2016). The China (Shanghai) pilot free trade zone: Background, developments and preliminary assessment of initial impacts. The World Economy, 39(1), 2-15. https://doi.org/10.3386/w20924

Yep, R. (2008). The 1967 riots in Hong Kong: the diplomatic and domestic fronts of the colonial governor. China Quarterly, 193, 122-139. https://doi.org/10.1017/s0305741008000076

Yep, R., \& Lui, T.L. (2010). Revisiting the golden era of MacLehose and the dynamics of social reforms. China Information, 24(3), 249-272. https://doi.org/10.1177/0920203×10379360

Yuen, S. (2014). Under the shadow of China: Beijing's policy towards Hong Kong and Taiwan in comparative perspective, China Perspectives, 2, 69-76.

Yuen, S, \& Cheng, E.W. (2017). Neither repression nor concession? A regime's attrition against mass protests. Political Studies, 65(3), 611-630. https://doi.org/10.1177/0032321716674024

Zhao, S. (2010). The China Model: can it replace the Western model of modernization? Journal of contemporary China, 19(65), 419-436. https://doi.org/10.1080/10670561003666061 